\title{
Effects of precipitation change and neighboring plants on population dynamics of Bromus tectorum
}

\author{
Janet S. Prevéy ${ }^{1,2} \cdot$ Timothy R. Seastedt $^{2}$
}

Received: 5 December 2014 / Accepted: 10 July 2015 / Published online: 31 July 2015

(C) Springer-Verlag Berlin Heidelberg 2015

\begin{abstract}
Shifting precipitation patterns resulting from global climate change will influence the success of invasive plant species. In the Front Range of Colorado, Bromus tectorum (cheatgrass) and other non-native winter annuals have invaded grassland communities and are becoming more abundant. As the global climate warms, more precipitation may fall as rain rather than snow in winter, and an increase in winter rain could benefit early-growing winter annuals, such as $B$. tectorum, to the detriment of native species. In this study we measured the effects of simulated changes in seasonal precipitation and presence of other plant species on population growth of $B$. tectorum in a grassland ecosystem near Boulder, Colorado, USA. We also performed elasticity analyses to identify life transitions that were most sensitive to precipitation differences. In both study years, population growth rates were highest for B. tectorum growing in treatments receiving supplemental winter precipitation and lowest for those receiving the summer drought treatment. Survival of seedlings to flowering and seed production contributed most to population growth in all treatments. Biomass of neighboring native plants was positively correlated with reduced population growth
\end{abstract}

Communicated by Katherine L Gross.

Electronic supplementary material The online version of this article (doi:10.1007/s00442-015-3398-z) contains supplementary material, which is available to authorized users.

Janet S. Prevéy

janet.prevey@gmail.com

1 Swiss Federal Institute for Forest, Snow and Landscape Research, Flüelastrasse 11, 7260 Davos Dorf, Switzerland

2 Department of Ecology and Evolutionary Biology, University of Colorado, UCB 450, Boulder 80309, CO, USA rates of B. tectorum. However, exotic plant biomass had no effect on population growth rates. This study demonstrates how interacting effects of climate change and presence of native plants can influence the population growth of an invasive species. Overall, our results suggest that $B$. tectorum will become more invasive in grasslands if the seasonality of precipitation shifts towards wetter winters and allows $B$. tectorum to grow when competition from native species is low.

Keywords Bromus tectorum - Demography · Climate change $\cdot$ Invasive species $\cdot$ Semi-arid grassland

\section{Introduction}

Climate change is expected to shift the distribution of plant species (Walther et al. 2002; Parmesan and Yohe 2003). Invasive species, in particular, may have traits that will allow them to benefit from climate change (Dukes and Mooney 1999; Thuiller et al. 2007; Hellmann et al. 2008). Accurately predicting how invasion risk will change as the climate changes is important for effective management and restoration strategies (Dukes and Mooney 1999; Bradley et al. 2009). Additionally, climate change will affect entire communities, not single species living in isolation, and research needs to address how changes in climate will affect interactions between biotic elements in an ecosystem to understand how any one species will be affected (Suttle et al. 2007; Adler et al. 2012). In this study we sought to examine how precipitation change associated with climate change may impact the invasive grass Bromus tectorum, one of the most ubiquitous non-native species in the Intermountain West, using a unique combination of empirical studies and demographic analyses. 
Bromus tectorum has invaded a large portion of rangelands in the Intermountain West since its introduction to the USA from Eurasia in the late 1800s (Mack 1981). Bromus tectorum can impact ecosystems by preempting soil resources before native plants are active, reducing plant diversity, altering nutrient cycling, and altering fire frequencies (Melgoza et al. 1990; D'Antonio and Vitousek 1992; Concilio et al. 2013). The success of this invasive grass is partially attributed to its plastic growth responses to changing conditions (Mack and Pyke 1983; Griffith et al. 2014). While B. tectorum has historically been a very successful invader in areas with winter-wet climate regimes, it is not as widespread in areas with more spring and summer precipitation (Mack 1989). However, some evidence indicates that $B$. tectorum and other winter-active non-native species are becoming more common in areas along the Front Range of Colorado (Bromberg et al. 2011; Bush et al. 2007) that historically received the majority of annual precipitation in spring and summer.

Climate predictions differ on exactly how precipitation will change in the future (IPCC 2013), but there is general agreement that as temperatures warm, more precipitation will fall as rain rather than snow in the winter in the eastern foothills of the Rockies (Ray et al. 2008; IPCC 2013). There has already been an increase in the fraction of winter precipitation falling as rain rather than snow along the Front Range of Colorado from 1949 through to 2004 (Knowles et al. 2006). Bioclimatic envelope analyses and results from manipulative experiments suggest that $B$. tectorum may respond positively to increased winter precipitation (Bradley 2009; Concilio et al. 2013; Zelikova et al. 2013), so understanding how shifting precipitation patterns associated with climate change affect this species will be important for management considerations.

Other factors may influence the success of B. tectorum in the foothills of Colorado. Competition from resident species can affect resource availability and contribute to the invasion resistance of ecosystems (e.g., Tilman 1997; Naeem et al. 2000; Corbin and D'Antonio 2004). Competition from established species may limit the ability of new species to invade (Kennedy et al. 2002) or, alternatively, neighboring plant species may have no effect, or even facilitate the establishment of new species (Bulleri et al. 2008; Griffith 2010). The outcomes of interactions between species may also shift under a changing climate (Dormann 2007; Concilio et al. 2013). On the other hand, competing species may not capitalize on changing precipitation patterns, and allow for an increase in unused resources available for invasive species (Davis et al. 2000). Species whose niches overlap with $B$. tectorum may experience stronger interactions with $B$. tectorum and climate change than species with large niche differences (MacDougall et al. 2009; Adler et al. 2012).
This study combines population matrix models and measures of neighboring plant species to obtain a more informed picture of how B. tectorum will respond to changing climatic conditions and also to changes in competition resulting from climate change. Specifically, we used a demographic approach to examine how population growth and transitions to different life stages respond to changes in precipitation. At the start of the study, we hypothesized that $B$. tectorum would have higher rates of population growth in plots receiving supplemental winter precipitation and that B. tectorum would be less successful in plots with greater biomass of neighboring plants. Finally, we predicted that increased winter precipitation would increase the biomass of other winter-active exotic plants at our site.

\section{Materials and methods}

\section{Field site}

The field site is in a mixed-grass prairie located approximately $15 \mathrm{~km}$ northwest of Boulder, Colorado, USA $\left(40^{\circ} 07^{\prime} \mathrm{N}, 105^{\circ} 18^{\prime} \mathrm{W}\right)$ at an elevation of $1798 \mathrm{~m}$ a.s.l. Average annual precipitation is $475 \mathrm{~mm} \mathrm{year}^{-1}$, and average annual temperature is $10.5{ }^{\circ} \mathrm{C}$ (WRCC 2014). The site has a continental climate, with most precipitation falling in spring and early summer. Soils at the field site are well drained, colluvial, sandy loams (USDA 2001). The site has been impacted by cattle grazing in the past and has now been substantially invaded by Bromus tectorum.

The plant community at the site is composed of a mix of winter-active exotic plant species and later-growing native plant species (Knochel 2009). The most common exotic species are B. tectorum, Bromus japonicus, Poa compressa, Erodium circutatum, Alyssum parviflorum, and Sisymbrium altissimum. The most common native species are Pascopyrum smithii, Sporobolus cryptandrus, Psoralidium tenuiflorum, Ambrosia artemisiifolia, and Erigeron flagellaris.

\section{Experimental design}

In June 2010, we established a precipitation manipulation experiment at the site. Precipitation manipulations were based on information from global climate circulation models (GCMs) and preliminary climate analyses of historical data from climate stations along the Front Range of Colorado (Prevéy 2014). GCMs disagree on how precipitation will change along the Colorado Front Range (IPCC 2013), but most models show increases in winter precipitation, and some show decreases in summer precipitation (Weltzin et al. 2003; IPCC 2013). To address this uncertainty in precipitation change, we established five precipitation treatments based on IPCC climate model predictions: control, 
winter-wet, winter-wet/summer-wet, winter-wet/summerdry, and winter-dry/summer-wet. We allocated each treatment to ten $2 \times 2-\mathrm{m}$ plots spread over an area of approximately 1 ha, for a total of 50 plots, from 01 June 2010 through to 30 September 2013. Treatments were randomly assigned to ten spatially aggregated blocks to account for heterogeneity across the site. To increase precipitation in the winter-wet and summer-wet precipitation treatments, we added water to plots during the periods October-March or June-September, respectively, using well water that is available at the study site. We added an amount of water to each plot that would increase total precipitation by approximately $50 \%$ above ambient precipitation in either season. Water was added to plots slowly with a sprinkler once or twice per week in 1-2 cm precipitation events during either the summer or winter (summer-wet or winterwet treatment, respectively). Our aim was to specifically test the effects of increased liquid precipitation that may be received in warmer years in the future. Thus, we only added water to plots on days that were above freezing. To decrease summer or winter precipitation in the summer and winter-dry treatments, we used passive deflection rain-out shelters that blocked $50 \%$ of incoming precipitation, based on the design of Yahdjian and Sala (2002). These rain-out shelters were designed to have minimal effects on wind speed, temperature, or incoming light (Yahdjian and Sala 2002). For this study, we excluded the winter-wet/summerwet treatments because $B$. tectorum senesces before we began with the summer precipitation additions, and abundance results for $B$. tectorum from the winter-wet/summerwet treatment were similar to those from other winter-wet treatments (Prevéy and Seastedt 2014). The exact amount of water added or withheld from each treatment is provided in Table 1.

\section{Demographic measurements}

We began demographic measurements of $B$. tectorum in November 2011, 1 year after initiation of the larger precipitation manipulation experiment. For this study, we first created one disturbed and seeded subplot within each of the ten plots in the four selected precipitation treatments. On 15 November 2011, half of each $2 \times 2$-m plot was disturbed to remove surface vegetation. We then monitored the demography of $B$. tectorum in a $0.1-\mathrm{m}^{2}$ subplot centered within the disturbed section of each plot [Electronic Supplementary Material (ESM) Fig. A1]. We removed all vegetation and litter from these subplots to create similar conditions between different plots and to enable us only to examine competition of plants growing at the same time as B. tectorum. Removing litter and vegetation also allowed us to better observe the germination and survival of $B$. tectorum individuals that would be otherwise difficult to detect in thatch and litter layers. Fifty B. tectorum seeds were sown in each subplot. Prior to sowing, soil samples (volume $141.4 \mathrm{~cm}^{3}$ ) were collected from the center of each subplot to a soil depth of $5 \mathrm{~cm}$ to estimate pre-existing seedbank size and seed viability. Soil samples were sieved to isolate $B$. tectorum seeds, and these seeds were counted and then placed between wet filter papers in petri dishes to test seed viability. The filter paper was kept moist over a 3-week period, and all seeds that germinated were counted and used to estimate the existing seedbank size in each plot. Every 2 weeks after sowing, from 25 November

Table 1 Precipitation and temperatures of the different treatment regimes over the study period (October 2011-August 2013)

\begin{tabular}{|c|c|c|c|c|c|c|}
\hline \multirow[t]{2}{*}{ Dates } & \multicolumn{4}{|c|}{ Precipitation treatments } & \multirow{2}{*}{$\begin{array}{l}\text { Average } \\
\text { precipitation } \\
(\mathrm{mm})^{\mathrm{a}}\end{array}$} & \multirow{2}{*}{$\begin{array}{l}\text { Temperature } \\
\left({ }^{\circ} \mathrm{C}\right)^{\mathrm{a}}\end{array}$} \\
\hline & Control (mm) & $\begin{array}{l}\text { Winter-wet } \\
(\mathrm{mm})\end{array}$ & $\begin{array}{l}\text { Winter-wet/ } \\
\text { summer-dry (mm) }\end{array}$ & $\begin{array}{l}\text { Winter-dry/ } \\
\text { summer-wet (mm) }\end{array}$ & & \\
\hline $\begin{array}{l}\text { Winter 2011/2012 } \\
\text { (Oct-Mar) }\end{array}$ & 123.21 & 237.21 & 237.21 & 61.61 & 160.78 & 5.31 \\
\hline $\begin{array}{l}\text { Spring } 2012 \\
\text { (April-May) }\end{array}$ & 74.93 & 74.93 & 37.47 & 74.93 & 142.49 & 14.03 \\
\hline $\begin{array}{r}\text { Summer } 2012 \\
\text { (June-Sept.) }\end{array}$ & 168.25 & 168.25 & 84.13 & 277.00 & 171.70 & 22.25 \\
\hline $\begin{array}{l}\text { Winter 2012/2013 } \\
\text { (Oct-Mar) }\end{array}$ & 134.10 & 209.10 & 209.10 & 67.05 & 160.78 & 4.09 \\
\hline $\begin{array}{l}\text { Spring } 2013 \\
\text { (April-May) }\end{array}$ & 162.31 & 162.31 & 81.15 & 162.31 & 142.49 & 10.42 \\
\hline $\begin{array}{l}\text { Summer } 2013 \\
\text { (June-Aug) }\end{array}$ & 59.39 & 59.39 & 41.20 & 139.39 & 133.35 & 21.91 \\
\hline
\end{tabular}

a 'Average precipitation.' is the long-term (1950-2000) average precipitation received in Boulder, CO, over the listed dates. Temperature and average precipitation data were obtained from the Boulder COOP weather station (WRCC 2014). Temperature values are average temperatures over the listed dates 
2011 through to 19 June 2011, we recorded the germination and survival of all B. tectorum individuals growing in the subplots; each individual was classified as a new seedling (1-2 leaves, height $<1 \mathrm{~cm}$ ) or as a surviving seedling ( $\geq 3$ leaves, height $>1 \mathrm{~cm}$, or formation of a basal rosette). On 20 June 2012, following the senescence of all B. tectorum in the subplots, we harvested all aboveground biomass in each subplot. The biomass of B. tectorum and all other plant species was sorted by species, then dried, and weighed. We also counted the number of seeds produced by each B. tectorum plant. Beginning in October 2012, we repeated the demographic censuses for another year. On 18 October 2012, we planted another 50 seeds in each subplot and monitored subplots every 2 weeks from 24 October 2012 through to 25 June 2013. In addition, to test seedbank viability, we placed $30 \mathrm{~B}$. tectorum seeds in mesh bags and buried the mesh bags at a soil depth of $5 \mathrm{~cm}$ below each subplot on 18 October 2012 (ESM Fig. A1). The mesh bags were harvested in May 2013, after all germination had occurred. Seeds in mesh bags were classified as germinated or ungerminated. All ungerminated seeds were placed in petri dishes with moist filter paper for 3 weeks to test for viability. On 26 June 2013, we harvested all aboveground biomass in each subplot and counted seeds using the same methods described above for 2012.

In 2012 and 2013, we also recorded infection of B. tectorum with the fungal pathogen Ustilago bullata to examine whether pathogen infection impacted seed production and population growth (Prevéy and Seastedt 2015). Ustilago bullata systematically infects $B$. tectorum as a seedling and then entirely co-opts seed production of the plant, causing the grass to produce spores of the fungus instead of viable seeds (Alexopoulos et al. 1996). To quantify the effects of the pathogen, we harvested six B. tectorum individuals per plot in June 2012 and eight individuals per plot in June 2013 at evenly spaced marked locations along a transect running through the middle of each plot. Individuals were dried, weighed, and inspected for $U$. bullata infection, and all viable seeds produced per individual were counted.

\section{Demographic analysis and model parameterization}

To determine how precipitation treatments affected population growth and the importance of different life stages of $B$. tectorum, we used information from demographic censuses to create population matrix models. We utilized stage-classified matrix models with a projection interval of one season (Fig. 1) and established five life stages for B. tectorum (Fig. 1). Probabilities of transitioning between life stages (e.g., $S_{1}, G_{3}$ ) were calculated using information from demographic censuses from fall 2011 to summer 2012, and from fall 2012 to summer 2013. Fecundity $\left(F_{1}\right)$ was calculated using the average seed production of $B$. tectorum in each

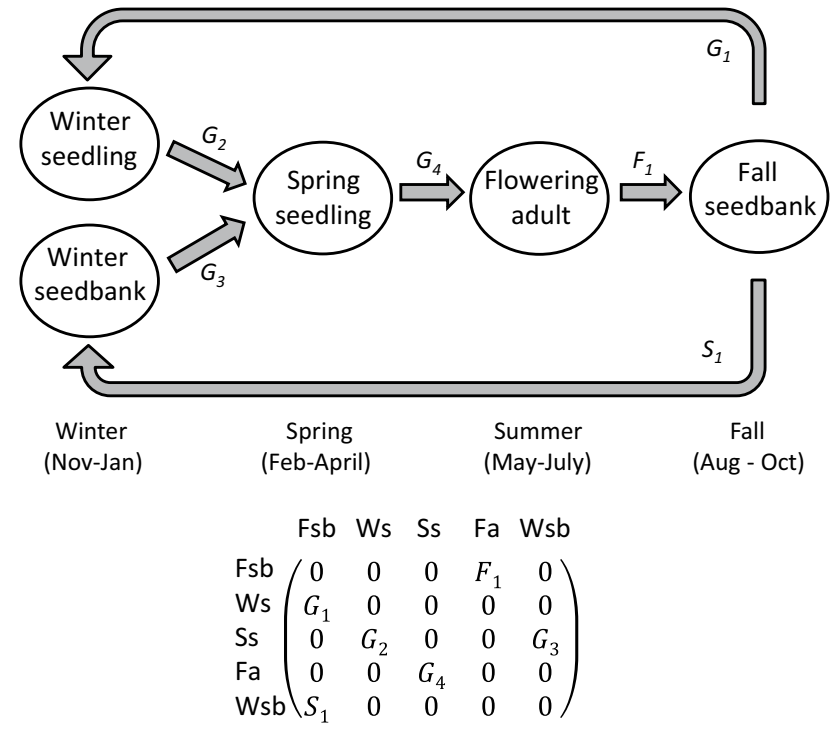

Fig. 1 Life cycles and stage-classified matrix population model for Bromus tectorum. The five stages in the model are winter seedbank $(W s b)$, fall seedbank $(F s b)$, winter seedlings $(W s)$, spring seedlings $(\mathrm{Ss})$, and flowering adults $(\mathrm{Fa})$. Arrows indicate transition between life stages $\left(S_{1}, G_{1}-G_{4}, F_{1}\right)$ with a probability of transition. The time scale for each transition is one season

plot. We decided not to include a seedbank that persisted for $>1$ year based on results from seed viability tests on the seeds in the mesh bags. There were no plots where we observed $>5 \%$ of seeds in the mesh bags that were ungerminated but were still viable after 1 year in the soil.

We calculated population growth rates separately for $B$. tectorum in each plot in each year as the dominant eigenvalues of the population matrix models ( $\lambda$, Caswell 2001). To examine how important transitions from different life stages were to population growth, we also performed elasticity analyses on average matrices from each treatment. All analyses were conducted using the popbio package in $\mathrm{R}$ (Stubben and Milligan 2007).

\section{Statistical analyses}

We modeled the following response variables separately using linear mixed-effects models: population growth rate of $B$. tectorum, seed production, percentage cover of $B$. tectorum in undisturbed plots, aboveground biomass of $B$. tectorum, and over-winter survival of B. tectorum. For each response we examined the additive and interactive effects of year, precipitation manipulations, competitor biomass, and pathogen infection. Plot and block were considered to be random effects in the models. We used the "step" function in the lmerTest package in R (Kuznetsova et al. 2014) to drop predictor variables that did not account for significant variation in the response variable from the final model. Linear mixed-effects models were also used to examine 
how precipitation treatments affected the biomass of native and exotic species growing in subplots. We analyzed the biomass of native and exotic plants separately because the two groups differ in their timing of active growth and therefore may be differentially affected by seasonal precipitation treatments, as well as differentially affect the population growth of B. tectorum. Percentage cover of B. tectorum and all aboveground biomass variables were square-root transformed before analysis to help meet assumptions of homogeneity of residuals. Significant differences between treatments and years at the $p<0.05$ level were calculated from F statistics based on Satterthwate's approximations of degrees of freedom for linear mixed-effects models (Kuznetsova et al. 2014). Data were analyzed using the lme4 package (Bates et al. 2011) and the lmerTest package (Kuznetsova et al. 2014) in the statistical program R (R Development Core Team 2012).

To examine possible competitive relationships in more detail, we used $B$. tectorum population growth rate as a response variable in a number of simple linear regressions. Predictor variables were: total neighbor biomass (native and exotic species), biomass of native species, and biomass of exotic species in each plot in 2012 and 2013. All biomass variables were square-root transformed before analysis. We used linear models to calculate $R^{2}$ and $p$ values for correlations of all biomass variables in 2012, as well as of total and exotic competitor biomass in 2013. Square-root transformed native biomass in 2013 did not fit assumptions of normality, so we used a Spearman's rank correlation to calculate correlation coefficients and $p$ values for the relationship between native biomass and population growth rates in 2013. The Spearman's rank correlation was performed using the Hmisc package in R (Harrell et al. 2012).

\section{Results}

Ambient precipitation received during spring over the 2 years of the experiment varied greatly. The spring of 2012 was very dry, whereas that of of 2013 was wetter than average (Table 1). Results from linear-mixed models revealed that precipitation treatment, year, and biomass of adjacent native plants significantly affected the population growth rates of B. tectorum over the study period (Table 2; Fig. 2a). Total biomass of neighboring plants and abundance of the pathogen $U$. bullata did not influence population growth rates in either year (all $p>0.44$ ). Population growth rates of B. tectorum were lower overall in 2012 than in 2013 and lowest in the winter-dry/summer-wet treatment in both years (Table 2; Fig. 2a).

Seed production of $B$. tectorum differed significantly between 2012 and 2013 (Table 2; Fig. 2b). Seed production was lowest in the winter-dry treatment in 2012, but highest in the winter-dry treatment in $2013(p=0.006)$. Cover of $B$. tectorum was significantly lower in the winter-dry treatment than in winter-wet treatments in both years $(p=0.0005$; Fig. 2c). Aboveground biomass of $B$. tectorum was lower in all treatments in 2012 than in $2013(p<0.0001)$.

Native plant biomass was highest in the winter-dry treatment in 2013 (Fig. 3a), and exotic plant biomass was highest in the winter-wet/summer-dry treatment in 2012, and higher overall in 2013 than in 2012 (Table 2; Fig. 3b). There were no significant correlations between total competitor biomass and population growth rates of $B$. tectorum in either 2012 or 2013 (all $R^{2}<0.09, p>0.07$ ). However, there were negative correlations between native plant biomass and population growth rates of $B$. tectorum in both years (Fig. 3c, e). There was a positive correlation between exotic plant biomass and population growth rates in 2012 (Fig. 3d), but no significant correlation in 2013 (Fig. 3f).

In 2012, results of the elasticity analyses revealed that survival of spring seedlings to flowering and seed production contributed more to population growth than other transitions in all treatments (Fig. 4). In 2013, however, elasticities for the winter-dry treatment differed from those of the other treatments. In the winter-dry treatment, survival of spring seedlings to flowering and seed production were the most important contributors to population growth, similar to elasticities of all treatments in 2012. In the winterwet and control treatments in 2013, the entire life history pathway for fall-emerging seedlings (germinating in fall, surviving over winter and spring, and producing seeds) contributed more to population growth rates than the life history pathway of seeds overwintering in the seedbank and germinating in the spring (Fig. 4).

\section{Discussion}

Changes in precipitation patterns resulting from climate change have the potential to impact population dynamics of invasive species. The results of this study show that increased winter precipitation benefitted population growth of B. tectorum, especially when the biomass of nearby native plants was low. Spring precipitation was also a large driver of differences in population growth rates, and population growth rates were higher for all treatments in 2013 after an unusually wet spring. Productivity, seed production, abundance, and overwinter survival all varied between treatments and years, demonstrating the sensitivity of $B$. tectorum to precipitation timing. The most important stages for population growth of $B$. tectorum were survival from seedling to flowering plant and seed production. Elasticity values also varied with precipitation treatments, showing that changes in precipitation can alter the most important life transitions for $B$. tectorum. 
Table 2 Results of linear mixed-effects models of demographic measurements of Bromus tectorum and aboveground biomass of neighboring plants in response to precipitation treatments ${ }^{\mathrm{a}}$

\begin{tabular}{|c|c|c|c|c|c|c|c|c|}
\hline \multirow[t]{2}{*}{ Response variable } & \multirow[t]{2}{*}{ Predictor variable } & \multirow{2}{*}{$\begin{array}{l}\text { Parameter } \\
\text { estimate }^{b}\end{array}$} & \multirow[t]{2}{*}{$d f$} & \multirow[t]{2}{*}{$t$} & \multirow[t]{2}{*}{$p(>t)$} & \multicolumn{3}{|l|}{ Variance $^{c}$} \\
\hline & & & & & & Block & Plot & Residual \\
\hline \multirow[t]{7}{*}{$\lambda^{\mathrm{d}}$ of Bromus tectorum } & Intercept & $1.46 \pm 0.19$ & $3,27.3$ & 7.50 & $<0.0001$ & $0.07 \pm 0.25$ & $0.07 \pm 0.28$ & $0.11 \pm 0.34$ \\
\hline & Winter-wet/summer-dry & $0.17 \pm 0.17$ & & 1.01 & 0.30 & & & \\
\hline & Winter-wet & $0.20 \pm 0.17$ & $3,27.3$ & 1.22 & 0.23 & & & \\
\hline & Winter-dry/summer-wet & $-0.32 \pm 0.17$ & $3,27.3$ & -1.95 & 0.06 & & & \\
\hline & Year & $0.17 \pm 0.14$ & $1,44.1$ & 1.23 & 0.22 & & & \\
\hline & Native biomass & $-0.21 \pm 0.09$ & 1,67 & -2.51 & 0.01 & & & \\
\hline & Year $\times$ native biomass & $0.22 \pm 0.08$ & $1,45.1$ & 2.72 & 0.009 & & & \\
\hline \multirow[t]{8}{*}{ Seed production } & Intercept & $5.23 \pm 0.46$ & & 11.47 & $<0.0001$ & $0.08 \pm 0.28$ & 0 & $1.1 \pm 1.41$ \\
\hline & Winter-wet/summer-dry & $1.84 \pm 0.63$ & 3,63 & 2.91 & 0.005 & & & \\
\hline & Winter-wet & $0.03 \pm 0.63$ & 3,63 & 0.04 & 0.97 & & & \\
\hline & Winter-dry/summer-wet & $-1.78 \pm 0.63$ & 3,63 & -2.81 & 0.007 & & & \\
\hline & Year & $1.67 \pm 0.63$ & 1,63 & 2.66 & 0.01 & & & \\
\hline & Year $\times$ summer dry & $-1.70 \pm 0.89$ & 3,63 & -1.90 & 0.06 & & & \\
\hline & Year $\times$ winter wet & $-0.45 \pm 0.89$ & 3,63 & -0.50 & 0.62 & & & \\
\hline & Year $\times$ winter dry & $2.54 \pm 0.89$ & 3,63 & 2.85 & 0.006 & & & \\
\hline \multirow[t]{4}{*}{ Cover of B. tectorum } & Intercept & $5.64 \pm 0.68$ & & 8.36 & $<0.0001$ & $2.03 \pm 1.42$ & $1.87 \pm 1.37$ & $1.32 \pm 1.16$ \\
\hline & Winter-wet/summer-dry & $1.97 \pm 0.71$ & 3,27 & 2.76 & 0.01 & & & \\
\hline & Winter-wet & $0.82 \pm 0.71$ & 3,27 & 1.16 & 0.26 & & & \\
\hline & Winter-dry/summer-wet & $-2.84 \pm 0.71$ & 3,27 & -3.99 & 0.0005 & & & \\
\hline \multirow[t]{2}{*}{ B. tectorum biomass } & Intercept & $0.27 \pm 0.02$ & & 16.56 & $<0.0001$ & $0.01 \pm 0.02$ & 0 & $0.01 \pm 0.09$ \\
\hline & Year & $0.15 \pm 0.02$ & $1,62.7$ & 7.07 & $<0.0001$ & & & \\
\hline Native plant biomass & Intercept & $1.38 \pm 0.24$ & & 5.75 & 0.0003 & $0.42 \pm 0.65$ & $0.45 \pm 0.67$ & $0.40 \pm 0.64$ \\
\hline \multirow[t]{5}{*}{ Exotic plant biomass } & Intercept & $1.54 \pm 0.24$ & & 6.37 & $<0.0001$ & $0.06 \pm 0.25$ & 0 & $0.84 \pm 0.92$ \\
\hline & Winter-wet/summer-dry & $0.61 \pm 0.29$ & 3,66 & 2.11 & 0.04 & & & \\
\hline & Winter-wet & $0.19 \pm 0.29$ & 3,66 & 0.67 & 0.51 & & & \\
\hline & Winter-dry/summer-wet & $-0.03 \pm 0.29$ & 3,66 & -0.10 & 0.92 & & & \\
\hline & Year & $1.07 \pm 0.20$ & 1,66 & 5.23 & $<0.0001$ & & & \\
\hline
\end{tabular}

${ }^{a}$ Only predictor variables that accounted for significant variation in the response variables were included in final analyses. All treatment estimates are compared to the control treatment. $P$ values and degrees of freedom $(d f)$ were calculated using the Satterthwaite approximation. All variables other than $\lambda$ of $B$. tectorum were square-root transformed before analysis

b Parameter estimate data are presented \pm standard error (SE)

c Variance data are presented \pm standard deviation (SD)

d $\lambda$, Eigenvalue of the respective population matrix model

Our results suggest that $B$. tectorum may become increasingly invasive in Colorado if the climate shifts to a more winter-wet regime. Consistent with our hypotheses, population growth increased in all treatments with increased winter precipitation. In 2012, winter drought led to decreasing population growth of B. tectorum, indicating that drier winters could decrease invasion success. However, in 2013, after an unusually wet spring, even $B$. tectorum in the winter-dry treatment had a high population growth rate, and population growth in all treatments was higher than those in 2012. These findings indicate that both winter and spring precipitation contribute to the success of B. tectorum. As such, they agree with those from bioclimatic envelope models showing winter and spring precipitation to be strong predictors of B. tectorum dominance throughout the Intermountain West (Bradley 2009). Plasticity in the timing of growth allows cheatgrass to take advantage of either ample winter or spring precipitation (Harris 1967; Mack and Pyke 1983; Concilio et al. 2013), increasing its probability of success in variable climates.

At our field site, a seedbank does not seem to play a large role in population dynamics of B. tectorum. We found little evidence of a seedbank that lasts for $>1$ year. Studies in other invaded areas have found a similar lack of dormancy over multiple years in B. tectorum seeds (Hulbert 1955; Griffith 2010), although some studies have found 
Fig. 2 Responses of B. tectorum to the four precipitation manipulations in 2012 and 2013. a Average population growth rates $(\lambda)$, b numbers of seeds produced per individual, c percentage cover, $\mathbf{d}$ aboveground biomass per individual of B. tectorum. Bars Means of the untransformed data, whiskers standard error (SE). Bars with different lowercase letters are significantly different from each other at the $p<0.05$ level. Significant differences were calculated from $F$ statistics based on the Satterthwate's approximations of degrees of freedom

Fig. 3 Top row Responses of neighboring plant biomass to the four precipitation manipulations in 2012 and 2013. a Average aboveground biomass of native plants, $\mathbf{b}$ average aboveground biomass of exotic plants growing in subplots in each treatment in 2012 and 2013.

Bars Means of the untransformed data, whiskers SE. Bars with different lowercase letters are significantly different from each other at the $p<0.05$ level. Middle and bottom rows Correlations of aboveground biomass of square-root transformed native plant neighbors (c, e) and square-root transformed exotic plant neighbors $(\mathbf{d}, \mathbf{f})$ to population growth rates of $B$. tectorum in 2012 (c, d), and 2013 (e, f) (a)
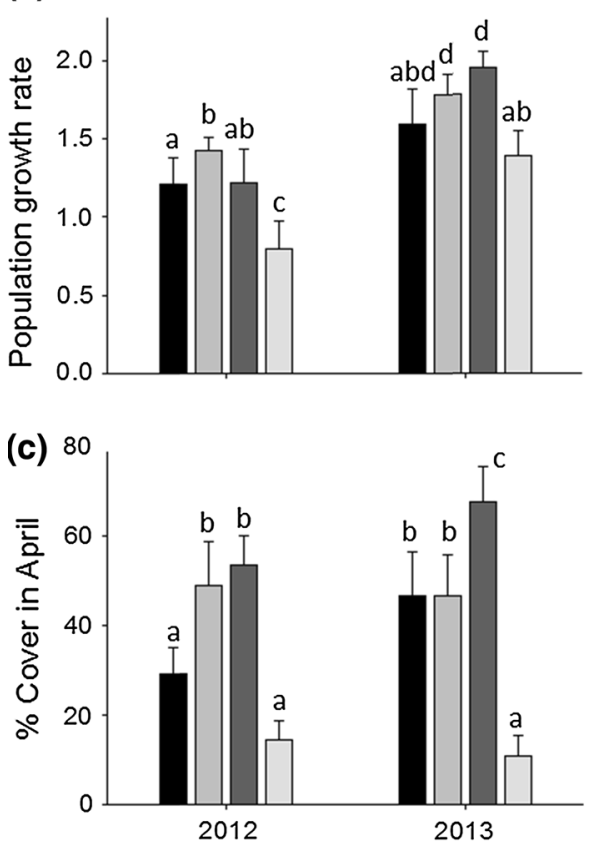

(a)

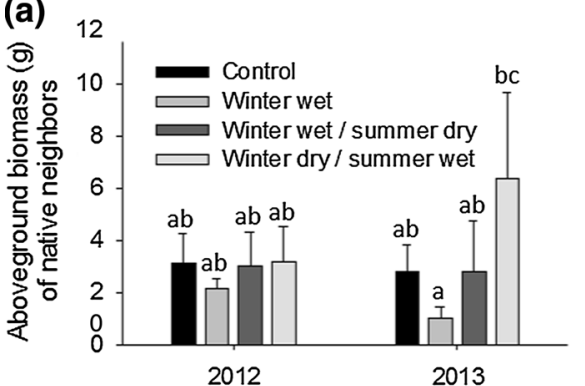

(c)

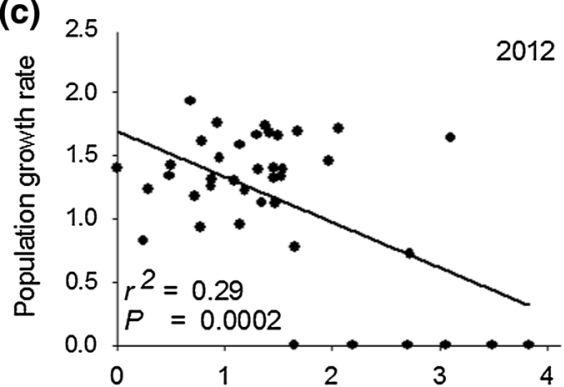

(e)

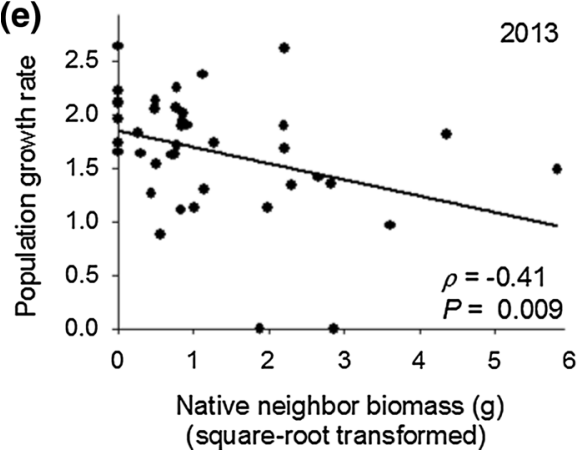

(b)
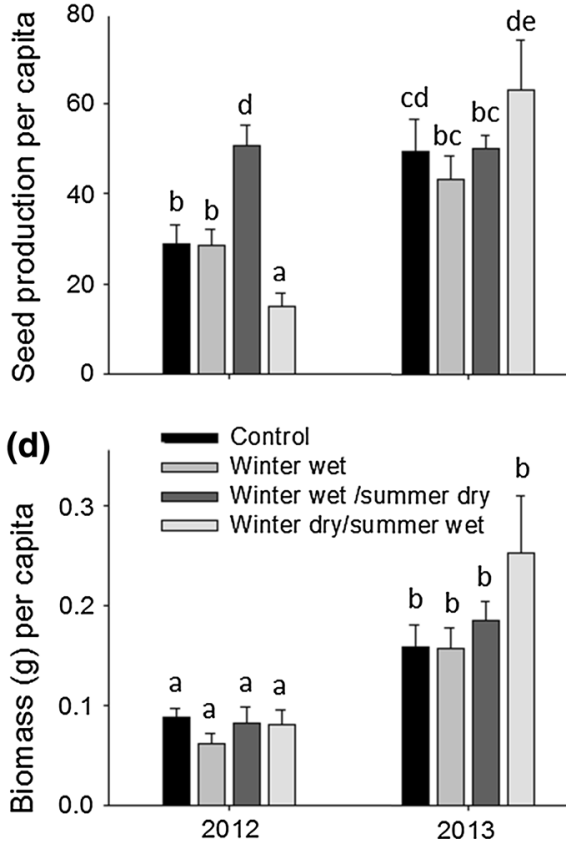

(b)
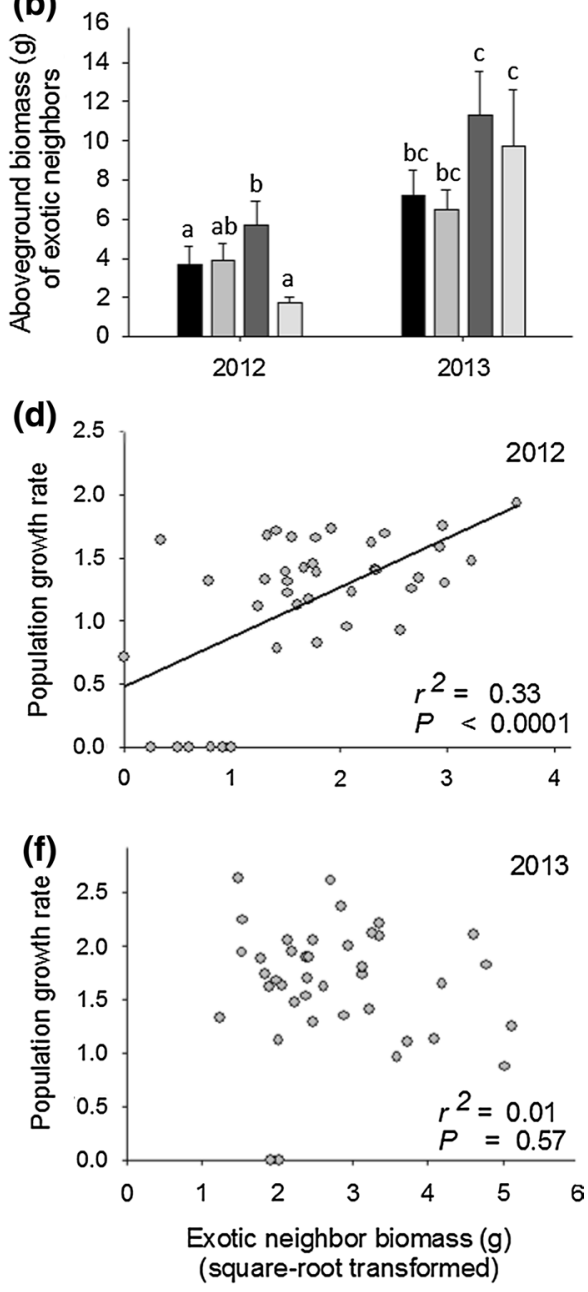
(a) 2012 All treatments

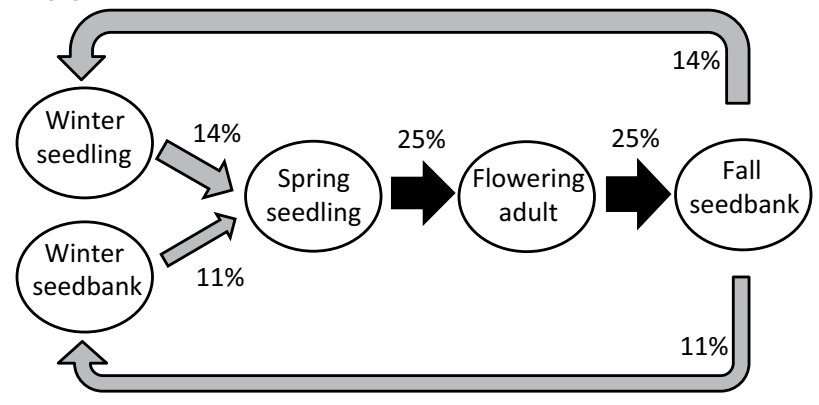

(b) 2013 Winter-wet and control treatments

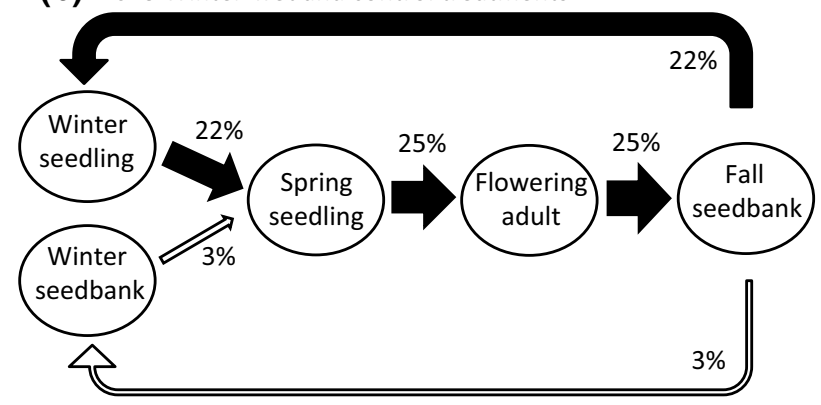

(c) 2013 Winter-dry/summer-wet treatment

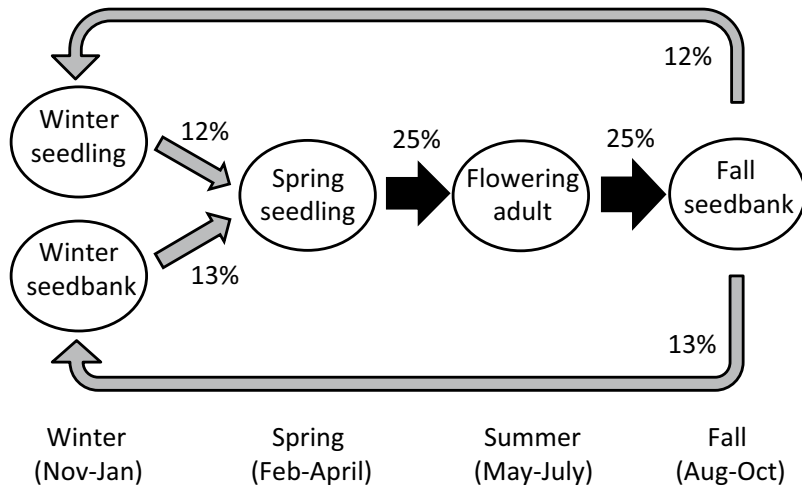

Fig. 4 Elasticities of population growth rates of B. tectorum in response to precipitation manipulations in 2012 and 2013. In 2012, all treatments had similar elasticities. In 2013, elasticities in the winter-dry/summer-wet treatment differed from those of the other treatments. Wider arrows with darker shading indicate transition probabilities that contribute most to population growth

viable seed that can last for $\geq 2$ years in litter layers and maintain B. tectorum populations after years of low seed production (Young et al. 1969; Young and Evans 1975). Since we removed litter from the subplots where we measured germination, we were unable to measure the longevity of seeds suspended in litter at our field site. Evidence from a California grassland suggests that other non-native annual grasses do not form long-lived seedbanks (Faist et al. 2013). These results are promising for control measures in ecosystems invaded by exotic annual grasses. If $B$. tectorum populations decline over a few years with dry winters and springs, it may be possible to eradicate-or at least significantly further reduce-this species from an area if management applications are timed accordingly (Prevéy et al. 2014).

There was a negative correlation between native plant biomass and population growth rates of B. tectorum. While our study did not directly manipulate the competitive environment, this negative correlation agrees with findings from previous research. At local scales, other studies have found similar associations between native and exotic species (Tilman 1997; Naeem et al. 2000), and several studies show that established native vegetation has the ability to limit the growth of B. tectorum (Chambers et al. 2014; Ponzetti et al. 2007; Reisner et al. 2013; Leger et al. 2014). In 2013, native species biomass was lower in the winter-wet treatment than in the winter-dry treatment, indicating that increased winter precipitation may lead to a reduction in native plants, which could further facilitate invasion of B. tectorum.

Interestingly, exotic competitor biomass did not reduce the population growth of $B$. tectorum, even though the biomass of other exotic species was often greater than that of native species in subplots. In 2012, exotic plant biomass was correlated with greater population growth rates of $B$. tectorum. All exotic species at the field site are winteractive annuals or perennials, and most are growing during the same time period as B. tectorum, so one might assume there would be greater competitive pressure because the species are occupying similar temporal niches (Adler et al. 2012). However, many of the other exotic species are taprooted forbs that are possibly using resources from different depths in the soil than B. tectorum. The positive association of exotic species has been observed multiple times in more heavily invaded areas (Piemeisel 1951; Kulmatiski 2006), but mechanisms driving these positive associations between exotic species remain unclear. Communities composed entirely of exotic species may remain in this alternative state for long periods and prevent the re-establishment of more diverse native communities (Simberloff and Von Holle 1999; Kulmatiski 2006).

The survival of $B$. tectorum seedlings in spring to flowering plants and seed production were the two most important transitions contributing to the population growth of $B$. tectorum in both years. This is logical, as seed production of an annual plant without a substantial seedbank determines the number of individuals in the next generation (Watkinson et al. 1989). Other studies have shown that even when there is a low density of $B$. tectorum individuals, if those individuals produce a large quantity of seeds, then populations can remain viable (Hulbert 1955). In 2013, the overwinter survival of seedlings that germinated in fall of 2012 was also very important to population growth, but only in the control and winter-wet treatments. Elasticity values in the winter-dry treatment were higher for seeds remaining viable in the seedbank until spring and for spring germination. Fall 
germination was low in the winter-dry treatment, with comparatively greater spring germination after a wet-up in the spring, making spring seedling germination a more important contributor to population growth after winter drought. Altering the timing of precipitation not only affected abundance and seed production of B. tectorum, it also changed the timing and relative importance of different life stages to population growth. Our elasticity analyses provide new information on how B. tectorum can adjust growth strategies to match the environment and further illustrate the ability of this species to alter its phenology to match climatic conditions (Beckstead et al. 1996). Management applications aimed to reduce spring seedling survival and seed production, such as spring grazing or burning, may be effective at reducing the population growth of B. tectorum.

This study has important implications for the management of disturbed or invaded ecosystems in a changing climate. Currently, climate and land use change are creating disturbances that can reduce competition from the resident community and increase the success of colonizing invasive plant species (Hobbs and Huenneke 1992; Dukes and Mooney 1999). Invasive species, such as B. tectorum, may be able to exploit changes in precipitation patterns that natives cannot. However, the findings of our study support the results of others showing that competition from native species is important and can deter invasion. Management actions that favor natives need to be considered along with management actions that directly reduce $B$. tectorum populations. Future invasibility of plant communities will not only be a function of changing climate, but also of levels of disturbance and the resilience of the existing plant community to climate change (Chambers et al. 2014; Reisner et al. 2013). Our research highlights the importance of considering the strong interactive effects that climate change and biotic change can have on the success of invasive species.

Acknowledgments Funding for this research was provided by an EPA STAR Graduate fellowship to J.S.P and NSF grant DEB 1120390 provided to T.R.S. We thank Peter Omasta, Bryan Todd, Zach Harmon, and Robin Reibold for assistance in the field and laboratory. We thank William Bowman, Sharon Collinge, Nichole Barger, John Dwyer, and two anonymous reviewers for providing helpful comments on earlier drafts of this manuscript. The experiments described here comply with the current laws of the USA.

Author contribution statement JSP and TRS conceived and designed the experiments. JSP performed the experiments, analyzed the data, and wrote the manuscript. TRS provided extensive editorial advice.

\section{References}

Adler PB, Dalgleish HJ, Ellner SP (2012) Forecasting plant community impacts of climate variability and change: when do competitive interactions matter? J Ecol 100:478-487. doi:10.1111/j.1365-2745.2011.01930.x

Alexopoulos CJ, Mims CW, Blackwell M (1996) Introductory mycology, 5th edn. John Wiley and Sons, New York

Bates D, Maechler M, Bolker B (2011) lme4: Linear mixed-effects models using S4 classes. R package version 0.999999-2. Available at: http://lme4.r-forge.r-project.org/. Accessed 4 Mar 2014

Beckstead J, Meyer SE, Allen PS (1996) Bromus tectorum seed germination: between-population and between-year variation. Can $\mathrm{J}$ Bot 74:875-882. doi:10.1139/b96-109

Bradley BA (2009) Regional analysis of the impacts of climate change on cheatgrass invasion shows potential risk and opportunity. Glob Change Biol 15:196-208. doi:10.1111/j.1365-2486.2008.01709.x

Bradley BA, Oppenheimer M, Wilcove DS (2009) Climate change and plant invasions: restoration opportunities ahead? Glob Change Biol 15:1511-1521. doi:10.1111/j.1365-2486.2008.01824.x

Bromberg JE, Kumar S, Brown CS, Stohlgren TJ (2011) Distributional changes and range predictions of downy brome (Bromus tectorum) in Rocky Mountain National Park. Invasive Plant Sci Manag 4:173-182. doi:10.1614/IPSM-D-10-00022.1

Bulleri F, Bruno JF, Benedetti-Cecchi L (2008) Beyond competition: incorporating positive interactions between species to predict ecosystem invasibility. PLoS Biol 6:e162. doi:10.1371/journal. pbio.0060162

Bush RT, Seastedt TR, Buckner D (2007) Plant community response to the decline of a dominant invasive plant, Centaurea diffusa, in a Colorado grassland. Ecol Restor 25:169-174. doi:10.3368/ er.25.3.169

Caswell H (2001) Matrix population models. John Wiley and Sons, Hoboken

Chambers JC, Bradley BA, Brown CS, D’Antonio C, Germino MJ, Grace JB, Hardegree SP, Miller RF, Pyke DA (2014) Resilience to stress and disturbance, and resistance to Bromus tectorum $\mathrm{L}$. invasion in cold desert shrublands of western North America. Ecosystems 17:360-375. doi:10.1007/s10021-013-9725-5

Concilio AM, Loik ME, Belnap J (2013) Global change effects on Bromus tectorum L. (Poaceae) at its high-elevation range margin. Glob Change Biol 19:161-172. doi:10.1111/gcb.12032

Corbin JD, D'Antonio CM (2004) Competition between native perennial and exotic annual grasses: implications for an historical invasion. Ecology 85:1273-1283. doi:10.1890/02-0744

D'Antonio CM, Vitousek PM (1992) Biological invasions by exotic grasses, the grass/fire cycle, and global change. Annu Rev Ecol Syst 23:63-87

Davis MA, Grime JP, Thompson K (2000) Fluctuating resources in plant communities: a general theory of invasibility. $\mathrm{J}$ Ecol 88:528-534. doi:10.1046/j.1365-2745.2000.00473.x

Dormann CF (2007) Promising the future? Global change projections of species distributions. Basic Appl Ecol 8:387-397. doi:10.1016/j.baae.2006.11.001

Dukes JS, Mooney HA (1999) Does global change increase the success of biological invaders? Trends Ecol Evol 14:135-139. doi:10.1016/S0169-5347(98)01554-7

Faist AM, Ferrenberg S, Collinge SK (2013) Banking on the past: seed banks as a reservoir for rare and native species in restored vernal pools. AoB Plants 5:plt043. doi:10.1093/aobpla/plt043

Griffith AB (2010) Positive effects of native shrubs on Bromus tectorum demography. Ecology 91:141-154. doi:10.1890/08-1446.1

Griffith AB, Andonian K, Weiss CP, Loik ME (2014) Variation in phenotypic plasticity for native and invasive populations of Bromus tectorum. Biol Invasions 16:2627-2638. doi:10.1007/ s10530-014-0692-3

Harrell FE, Dupont C, and many others (2012) Hmisc: Harrell Miscellaneous. $\mathrm{R}$ package version 3.10-1. Available at: http:// CRAN.R-project.org/package=Hmisc. Accessed 20 Dec 2014 
Harris GA (1967) Some competitive relationships between Agropyron spicatum and Bromus tectorum. Ecol Monogr 37:89-111. doi: $10.2307 / 2937337$

Hellmann JJ, Byers JE, Bierwagen BG, Dukes JS (2008) Five potential consequences of climate change for invasive species. Conserv Biol 22:534-543. doi:10.1111/j.1523-1739.2008.00951.x

Hobbs RJ, Huenneke LF (1992) Disturbance, diversity, and invasion: implications for conservation. Conserv Biol 6:324-337

Hulbert LC (1955) Ecological studies of Bromus tectorum and other annual bromegrasses. Ecol Monogr 25:181-213. doi: $10.2307 / 1943550$

IPCC (2013) Climate change 2013: the physical science basis. Contribution of Working Group I to the Fifth Assessment. In: Stocker TF, Qin D, Plattner GK, Tignor M, Allen SK, Boschung J, Nauels A, Xia Y, Bex V and Midgley PM (eds)Report of the Intergovernmental Panel on Climate Change. Cambridge University Press, Cambridge/New York USA. Available at: http://www.ipcc. ch/report/ar5/wg1/. Accessed 26 Nov 2013

Kennedy TA, Naeem S, Howe KM, Knops JMH, Tilman D, Reich P (2002) Biodiversity as a barrier to ecological invasion. Nature 417:636-638. doi:10.1038/nature00776

Knochel DG (2009) Interactions among herbivory, soil resources, and plant competition govern the recruitment and dominance of spotted knapweed (Centaurea stoebe) in North America. PhD dissertation. University of Colorado at Boulder, Boulder, $\mathrm{CO}$

Knowles N, Dettinger MD, Cayan DR (2006) Trends in snowfall versus rainfall in the western United States. J Clim 19:4545-4559. doi:10.1175/JCLI3850.1

Kulmatiski A (2006) Exotic plants establish persistent communities. Plant Ecol 187:261-275. doi:10.1007/s11258-006-9140-5

Kuznetsova A, Brockhoff PB, Christensen RHB (2014). lmerTest: Tests in Linear Mixed Effects Models. R package version 2.0-20. http://CRAN.R-project.org/package=lmerTest. Accessed 17 Mar 2015

Leger EA, Goergen EM, Forbis de Queiroz T (2014) Can native annual forbs reduce Bromus tectorum biomass and indirectly facilitate establishment of a native perennial grass? J Arid Environ 102:9-16. doi:10.1016/j.jaridenv.2013.10.015

MacDougall AS, Gilbert B, Levine JM (2009) Plant invasions and the niche. $\mathrm{J}$ Ecol 97:609-615. doi:10.1111/j.1365-2745.2009.01514.x

Mack RN (1981) Invasion of Bromus tectorum L. into Western North America: an ecological chronicle. Agro-Ecosystems 7:145-165. doi:10.1016/0304-3746(81)90027-5

Mack RN (1989) Temperate grasslands vulnerable to plant invasions: characteristics and consequences. Drake JA, DiCastri F, Groves RH, Kruger FJ, Rejmanek M, Williamson M (eds) Biological invasions: a global perspective, John Wiley \& Sons, Hoboken, pp $155-179$

Mack R, Pyke DA (1983) The demography of Bromus tectorum: variation in time and space. J Ecol 71:69-93. doi:10.2307/2259964

Melgoza G, Nowak RS, Tausch RJ (1990) Soil water exploitation after fire: competition between Bromus tectorum (cheatgrass) and two native species. Oecologia 83:7-13. doi:10.1007/BF00324626

Naeem S, Knops JM, Tilman D, Howe KM, Kennedy T, Gale S (2000) Plant diversity increases resistance to invasion in the absence of covarying extrinsic factors. Oikos 91:97-108. doi:10.1034/j.1600-0706.2000.910108.x

Parmesan C, Yohe G (2003) A globally coherent fingerprint of climate change impacts across natural systems. Nature 421:37-42. doi:10.1038/nature01286

Piemeisel RL (1951) Causes affecting change and rate of change in a vegetation of annuals in Idaho. Ecology 32:53-72. doi: $10.2307 / 1930972$

Ponzetti JM, McCune B, Pyke DA (2007) Biotic soil crusts in relation to topography, cheatgrass and fire in the
Columbia Basin, Washington. The Bryologist 110:706-722. doi:10.1639/0007-2745(2007)110[706:BSCIRT]2.0.CO;2

Prevéy JS (2014) Precipitation change in a semi-arid grassland: plant community responses and management strategies. $\mathrm{PhD}$ dissertation. University of Colorado at Boulder, Boulder

Prevéy JS, Seastedt TR (2014) Seasonality of precipitation interacts with exotic species to alter composition and phenology of a semi-arid grassland. J Ecol 102:1549-1561. doi:10.1111/1365-2745.12320

Prevéy JS, Seastedt TR (2015) Increased winter precipitation benefits the native plant pathogen Ustilago bullata that infects an invasive grass. Biol Invasions. doi:10.1007/s10530-015-0934-z

Prevéy JS, Knochel DG, Seastedt TR (2014) Mowing reduces exotic annual grasses but increases exotic annual forbs in a semi-arid grassland. Restor Ecol 22:774-781. doi:10.1111/rec.12140

R Development Core Team (2012) R: a language and environment for statistical computing. R Foundation for Statistical Computing, Vienna. Available at: http://www.R-project.org/. Accessed 16 July 2015

Ray AJ, Barsugli JJ, Averyt KB, Wolter K, Hoerling M (2008) Climate change in Colorado. A synthesis to support water resources management and adaptation. Colorado Water Conservation Board, Boulder, CO. Available at: http://wwa.colorado.edu/publications/reports/WWA_ClimateChangeColoradoReport_2008. pdf. Accessed 13 Apr 2014

Reisner MD, Grace JB, Pyke DA, Doescher PS (2013) Conditions favouring Bromus tectorum dominance of endangered sagebrush steppe ecosystems. J Appl Ecol 50:1039-1049. doi:10.1111/1365-2664.12097

Simberloff D, Von Holle B (1999) Positive interactions of nonindigenous species: invasional meltdown? Biol Invasions 1:21-32. doi :10.1023/A:1010086329619

Stubben CJ, Milligan BG (2007) Estimating and analyzing demographic models using the popbio package in R. J Stat Softw 22:11

Suttle KB, Thomsen MA, Power ME (2007) Species interactions reverse grassland responses to changing climate. Science 315:640-642. doi:10.1126/science.1136401

Thuiller W, Richardson DM, Midgley GF (2007) Will climate change promote alien plant invasions? In: Nentwig W (ed) Ecological studies. Springer, Berlin, pp 197-211

Tilman D (1997) Community invasibility, recruitment limitation, and grassland biodiversity. Ecology 78:81-92. doi: 10.1890/0012-9658(1997)078[0081:CIRLAG]2.0.CO;2

USDA (2001) Web Soil Survey. Natural Resources Conservation Center. Available at: http://websoilsurvey.nrcs.usda.gov/app/ WebSoilSurvey.aspx. Accessed 1 Aug 2011

Walther GR, Post E, Convey P, Menzel A, Parmesan C, Beebee TJC, Fromentin J, Hoegh- Guldberg O, Bairlein F (2002) Ecological responses to recent climate change. Nature 416:389-395. doi:10.1038/416389a

Watkinson AR, Lonsdale WM, Andrew MH (1989) Modeling the population dynamics of an annual plant Sorghum intrans in the wet-dry tropics. J Ecol 77:162-181. doi:10.2307/2260923

Weltzin JF, Loik ME, Schwinning S, Williams DG, Fay PA, Haddad BM, Harte J, Huxman TE, Knapp AK, Lin G, Pockman WT, Shaw MR, Small EE, Smith MD, Smith SD, Tissue DT, Zak JC (2003) Assessing the response of terrestrial ecosystems to potential changes in precipitation. Bioscience 53:941-952. doi:10.1641/0006-3568

Western Regional Climate Center (WRCC) (2014) Climate summary for Boulder, Colorado. Available at: http://www.wrcc.dri.edu/ cgi-bin/cliMAIN.pl?co0848. Accessed 4 June 2015

Yahdjian L, Sala OE (2002) A rainout shelter design for intercepting different amounts of rainfall. Oecologia 133:95-101. doi:10.1007/s00442-002-1024-3 
Young JA, Evans RA (1975) Germinability of seed reserves in a big sagebrush community. Weed Sci 23:358-364

Young JA, Evans RA, Eckert RE (1969) Population dynamics of downy brome. Weed Sci 17:20-26
Zelikova TJ, Hufbauer RA, Reed SC, Wertin T, Fettig C, Belnap J (2013) Eco-evolutionary responses of Bromus tectorum to climate change: implications for biological invasions. Ecol Evol 3:1374-1387. doi:10.1002/ece3.542 